МРНТИ 06.77.59

\author{
Джумамбаев С.К. \\ к.э.н., доцент, Казахский национальный университет им. аль-Фараби, \\ Казахстан, г. Алматы, e-mail: s.jumambayev@gmail.com

\section{ПРОБАЕМЫ ПРОГНОЗИРОВАНИЯ СПРОСА НА РАБОЧУЮ СИАУ НА РЫНКЕ ТРУАА B KAЗАХCTAHE}

\begin{abstract}
Условием успешной реализации третьей модернизации Казахстана является обеспечение эфффективного функционирования рынка труда. Аействующая модель казахстанского рынка труда в основном исчерпала свой потенциал в качестве драйвера экономического роста. Ее модернизация с учетом опыта развитых стран мира и особенностей развития страны позволит осуществить более точный прогноз параметров рынка труда, в том числе спроса на рабочую силу. Этой проблеме отечественной наукой и практикой не уделяется должного внимания.

Цель статьи состоит в адаптации современного методического инструментария анализа и прогнозирования спроса на рабочую силу к казахстанским Аанным. Рассмотрены особенности социально-экономического развития страны в аспекте их влияния на количественную сторону спроса на рабочую силу, слелан выбор основных факторов, воздействующих на изменение занятости, выведена экономико-математическая моде^ь Аля прогнозирования спроса на рабочую силу. Примененная методология исследования позволила впервые в Казахстане установить и оценить доминирующее влияние на изменение занятости Авух макроэкономических факторов: Аинамики ВВП и инвестиций.

Практическая значимость: результаты исследования можно использовать в дальнейшем А^я анализа и прогнозирования спроса на рабочую силу. Обоснована необходимость создания Института (центра) трудовых исследований, финансируемого из государственного бюджета.

Кмючевые слова: рынок труда Казахстана, модернизация, прогнозирование спроса на рабочую силу.
\end{abstract}

Jumambayev S.K.

candidate of economic sciences, associate professor, Al-Farabi Kazakh National University, Kazakhstan, Almaty, e-mail: s.jumambayev@gmail.com

\title{
Problems of forecasting demand for working force in the labor market in Kazakhstan
}

The condition for the successful implementation of the third modernization of Kazakhstan is to ensure the effective functioning of the labor market. The current model of the Kazakhstan labor market has largely exhausted its potential as

a driver of economic growth. Its modernization, taking into account the experience of the developed countries of the world and the peculiarities of the country's development, will make it possible to carry out a more accurate forecast of the parameters of the labor market, including the demand for labor. This problem is not given due attention by domestic science and practice.

The goal of the article is to adapt modern methodological tools for analyzing and forecasting the demand for labor to Kazakhstani data. The features of the socio-economic development of the country in terms of their impact on the quantitative side of the demand for labor are considered, the choice of the main factors influencing the change in employment is made, the economic-mathematical model for predicting the demand for labor is derived. The applied research methodology allowed for the first time in Kazakhstan to establish and assess the dominant influence on employment change of two macroeconomic factors: the dynamics of GDP and investment. 
Practical significance: the results of the study can be used in the future to analyze and predict the demand for labor. The necessity of creating a labor research institute (center) funded from the state budget is substantiated.

Key words: Kazakhstan labor market, modernization, forecasting the demand for labor.

\author{
Жұмамбаев С.К. \\ э.ғ.к., Аоцент, әл-Фараби атындағы Қазақ, ұлттық, университеті, \\ Қазақстан, Алматы қ., е-mail: s.jumambayev@gmail.com

\section{Қазақстанның еңбек нарығында жұмыс күшіне сұранысты болжау мәселемері}

\begin{abstract}
Еңбек нарығының тиімді қызметін қамтамасыз ету Қазақстанның үшінші жаңғыруын табысты іске асырудың шарты болады. Қазіргі еңбек нарығының қазақстандық моделі экономика өсуінің Арайвері ретінде өзінің әлеуетін негізінен тауысты. Әлемдегі дамыған елдердің тәжірибесін және өз еліміздің даму ерекшеліктерін ескеріп оны жаңғырту еңбек нарығының параметрлерін, оның ішінде жұмыс күшіне сұранысты дәлірек болжауға мүмкіндік береАі. Бұл мәселеге отандық, ғылым мен тәжірибе тиісті көңі^ бөлмейді.

Мақаланың мақсаты жұмыс күшіне сұранысты та^дау мен болжауға арналған заманауи әдістемелік тәсілдерді қазақстандық деректерге жерсіндіру. Осы мақсатта жұмыс күшіне сұраныстың сандық жағына елдің әлеуметтік-экономикалық даму ерекшеліктерінің ықпал жасау аспекті қарастырылған, жұмыспен қамтылу өзгеруіне әсер еткен негізгі факторлар таңдалған, жұмыс күшіне сұранысты болжауға арналған экономикалық-математикалық модель шығарылған. Қолданған зерттеу әдіснамасы Қазақстанда бірінші рет жұмыспен қамтылуының өзгеруіне екі макроэкономикалық фактордың - ЖІӨ мен инвестициялардың динамикасының -басым ықпалын анықтауға және оны бағалауға мүмкіндік туғызды.

Тәжірибелік маңыздылығы: зерттеу нәтижелерін бұдан былай жұмыс күшіне сұранысты талдауға және болжауға пайдалануға болады. Мемлекеттік бюджеттен қаржыландыратын еңбекті зерттеу Институтын (орталығын) ашу қажеттілігі дәлелденген.
\end{abstract}

Түйін сөздер: Қазақстанның еңбек нарығы, жаңғырту, жұмыс күшіне сұранысты болжау.

\section{Введение}

Осуществляемые социально-экономические преобразования, в соответствии с задачами третьей модернизацией Казахстана, сталкиваются с рядом проблем, в том числе и с проблемой обеспечения эффективного функционирования рынка труда. Опыт прошлых лет свидетельствует, что реформированию трудовых отношений в нашей стране не уделялось достаточного внимания. В трудовое законодательство часто вносились изменения и дополнения, со стороны государства осуществлялся слабый контроль за процессами, происходящими на рынке труда.

Несмотря на достигнутый низкий уровень безработицы, ситуация на рынке труда является достаточно сложной: низкая производительность труда, недостаток квалифицированных кадров, низкая мобильность рабочей силы, наличие значительной неформальной занятости. По данным Комитета по статистике Министерства национальной экономики Республики Казахстан (КС МНЭ РК), неформальная занятость в 2017 году составила почти 1,4 млн. человек, что оказывает заметное влияние на социально-экономическую ситуацию в стране. В экономике страны в 2017 году рост номинальной заработной платы составил $105,5 \%$, инфляции - 107,1\%, прожиточного минимума трудоспособного населения - $110,0 \%$, что также свидетельствует о наличии нерешенных проблем в социально-трудовой cфере.

Сложившаяся ситуация на рынке труда в Казахстане требует модернизации рынка труда, что предполагает всесторонний и обстоятельный анализ рынка труда, в том числе выявление основных тенденций изменения занятости и разработку научно обоснованных прогнозов спроса на рабочую силу.

В научной и учебной литературе представлены различные методы прогнозирования занятости. Однако, как отмечают многие исследователи, вне зависимости от сложности используемой методики точность и достоверность получаемых прогнозных оценок относительно невысока. Это во многом обусловлено необходимостью тщательного учета особенностей социальноэкономического развития исследуемой страны. Макроэкономическая ситуация в течение 20002017 гг. оказывала позитивное воздействие на рынок труда в Казахстане: уровень безработицы снизился на 7,9 п.П., и в 2017 году он составил 
4,9\% от численности экономически активного населения (рисунок 1).

Однако положительная тенденция снижения уровня общей безработицы не решает всех проблем рынка труда, и вполне ожидаемо, например, что проблема несоответствия спроса и предложения объективно будет обостряться в связи с третьей модернизацией Казахстана. Из проведенного автором сопоставления данных об уровне безработицы в Казахстане и ряде развитых стран можно заключить, что безработица в Казахстане не является большой проблемой. Если обратиться к статистическим данным стран ОЭСР, то можно видеть, что во Франции, Ита- лии, Финляндии и других странах уровень безработицы значительно превышает казахстанский уровень (OECD Data). Однако такое сравнение не учитывает несоответствие в уровне экономического развития Казахстана и развитых стран. В первую очередь речь идет о степени социальной защищенности безработных. Для большинства развитых стран численность безработных по методологии МОТ практически совпадает с численностью официально зарегистрированных безработных. А размер пособия по безработице в среднем может достигать в отдельных странах ОЭСР до 65\% средней заработной платы работника перед увольнением.

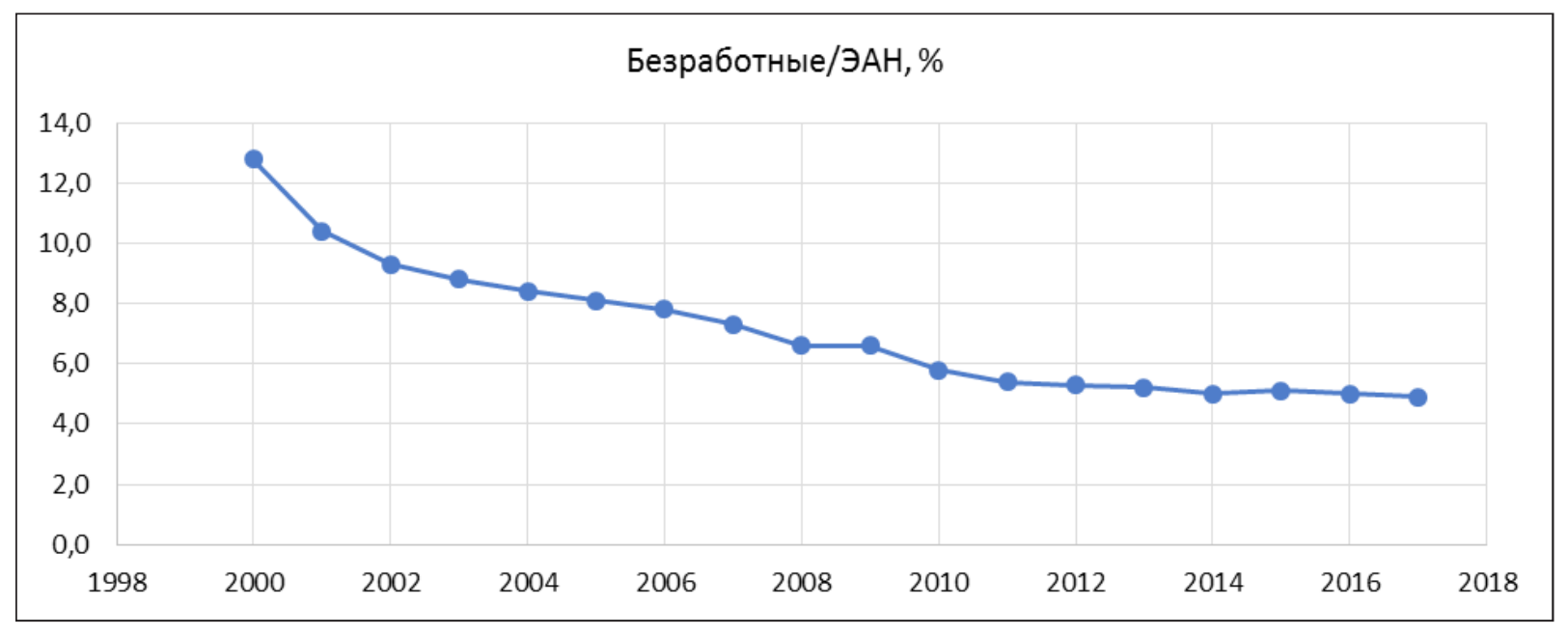

Рисунок 1 - Динамика безработицы в Казахстане в 2000-2017 гг.

В Казахстане в 2017 году из 442,3 тысяч безработных по методологии МОТ только 70,3 тысяч, т.е. лишь 15,9\%, официально зарегистрированы в службе занятости; социальную выплату на случай потери работы получили 36 тысяч человек $(8,1 \%$ и $51,2 \%$ соответственно от общего и официально зарегистрированного числа безработных), ее средний размер составил 21 тысячу тенге, то есть лишь $13,9 \%$ от средней заработной платы в стране. Под влиянием цифровизации в трудовую жизнь будет вступать все больше новых квалифицированных кадров с возросшими потребностями и иной мотивацией к труду. Уже сейчас в странах ОЭСР растет как абсолютное число, так и доля специалистов в области информационно-коммуникационных технологий в общем числе занятых. В 2017 г. в Казахстане доля отрасли ИКТ в общем числе занятых составила $1,5 \%$, резко возрос индекс физического объема инвестиций в основной капитал отрасли ИКТ - 127,0\%. Цифровизация вносит количественные и качественные сдвиги на рынке труда.

Поэтому необходимы принципиально новые подходы в решении проблем прогнозирования и моделирования рынка труда, в том числе занятости на макроуровне.

К сожалению, прогнозу спроса на рабочую силу и профессионально-квалификационной структуры занятости не уделяется должного внимания со стороны отечественной науки и практики. Трудовая сфера не включена в систему макроэкономического прогнозирования. Практика прогнозирования спроса на рабочую силу в Казахстане основана на данных, предоставляемых работодателями, что вызывает разрыв в оценках потребности в рабочей силе на уровне предприятий и на макроуровне. Также следует отметить недостаточность статистических данных для прогнозно-аналитических расчетов. 
Таким образом, одной из основных задач модернизации рынка труда в Казахстане становится применение современных методов анализа и прогноза процессов, происходящих на рынке труда. В данной статье автор попытался адаптировать методологию прогнозирования спроса на рабочую на макроуровне под казахстанские данные. В дальнейшем он может стать импульсом к началу проведения широких и углубленных исследований в Казахстане по прогнозу спроса на рабочую силу с использованием современных методов анализа и прогнозирования отраслевой и профессионально-квалификационной структуры занятости.

\section{Материалы и методы}

Для казахстанского рынка труда до сих пор остаются неизученными вопросы разработки методического инструментария анализа и прогнозирования и экономико-математических моделей для прогнозных расчетов показателей спроса на рабочую силу на макроуровне, оценки влияния макроэкономических факторов на динамику спроса на рабочую силу и др.

Чтобы провести обоснованный анализ и прогноз спроса на рабочую силу, он должен стать важным звеном макроэкономического прогнозирования развития экономики. Это предопределяет тесную связь между статистическими данными по труду и макроэкономическими показателями. Разработка методологии такого анализа и прогноза должна предполагать обязательный учет особенностей социально-экономического развития страны. Для исследования рассматриваемой проблемы нами привлечены официальные статистические данные КС МНЭ РК за период с 2001 по 2017 гг. Кроме того, для сравнительного анализа использованы статистические данные ряда развитых стран Организации экономического сотрудничества и развития, которые придерживаются различных моделей рынка труда

В научной и учебной литературе центральное место отводится определению спроса на рабочую силу на основе измерения влияния на его величину показателей изменения заработной платы. По нашим расчетам, при повышении среднегодового уровня реальной заработной платы в Казахстане в период с 2001 по 2017 гг. на один процент спрос на рабочую силу в среднем за этот период: в целом по экономике - повышался на $0,32 \%$, в сельском, лесном и рыбном хозяйстве - уменьшался на $0,12 \%$, горнорудной промышленности - повышался на 0,29\%, строительстве - на $0,43 \%$, образовании - на $0,27 \%$, здравоохранении - на $0,17 \%$, оптовой и розничной торговле - на $0,13 \%$, обрабатывающей отрасли - на 0,01\%. Эти данные свидетельствуют о том, что реакция спроса на рабочую силу на изменение заработной платы в отдельных видах экономической деятельности разнится существенно. И в целом по экономике страны за указанный период средний коэффициент эластичности численности занятых к реальной заработной плате составил 0,32 .

Количественное определение объема спроса на рабочую силу вызывает большие трудности. Объем спроса на рабочую силу складывается из суммы двух составляющих: численности занятых и числа вакантных рабочих мест. Между тем в казахстанской практике количество имеющихся вакансий рассматривают как условно постоянную величину. Так, несмотря на существенные изменения в экономике, в течение ряда последних лет в официальной статистике процент вакантных рабочих мест к численности работников стабильно составляет $0,9 \%$. В результате динамика спроса на рабочую силу полностью совпадает с динамикой занятости, в результате при прогнозировании спроса на рабочую силу приходится заменять его показателем занятости. Некоторые авторы полагают, что такой учет динамики вакантных рабочих мест при прогнозировании величины спроса на рабочую силу может увеличивать ошибку прогноза более чем в два раза (Кузнецов, 2015).

На наш взгляд, для решения этой проблемы можно предложить простой метод, который применяется в отдельных развитых странах (Franz, 2013). Он состоит в том, что службой занятости проводятся выборочное обследование предприятий и организаций различных регионов и отраслей с целью детального выяснения количества фактически имеющихся вакантных рабочих мест. Затем они сопоставляются с данными, которые они официально сообщают в службы занятости. В результате сопоставления выводят коэффициенты корректирования, использование которых дает возможность представить более реальную картину о свободных местах. При этом учитываются не только их количество, но и период времени, в течение которого они остаются незанятыми.

Спрос на рабочую силу определяют предприятия, организации и учреждения различных форм собственности. Учет формы собственности предприятия принципиально важен, так 
как частный и государственный сектора различаются целью и критериями выбора решений, в том числе и в вопросе о том, сколько труда использовать. В настоящее время численность работников, занятых в частном секторе материального производства и сферы услуг, является преобладающей. Высокая доля работников, занятых в государственном секторе, имеет место в образовании, здравоохранении и социальных услугах, государственном управлении. В определении объема спроса на рабочую силу преимущественную роль играет рынок наемно- го труда. В 2017 г. численность занятого населения в государственной форме собственности составила 2736,9 тыс. чел. (31,9\%), в частной 5407,6 тыс. чел. $(63,0 \%)$. Занятое население по статусу занятости: наемные работники - 6485,9 тыс. чел. (75,54\%), самостоятельно занятые работники - 2099,2 тыс. чел. (24,45\%) (Комитет по статистике, 2017).

В исследовании спроса на рабочую силу большое внимание необходимо уделить тенденциям занятости по секторам национальной экономики (рисунок 2).

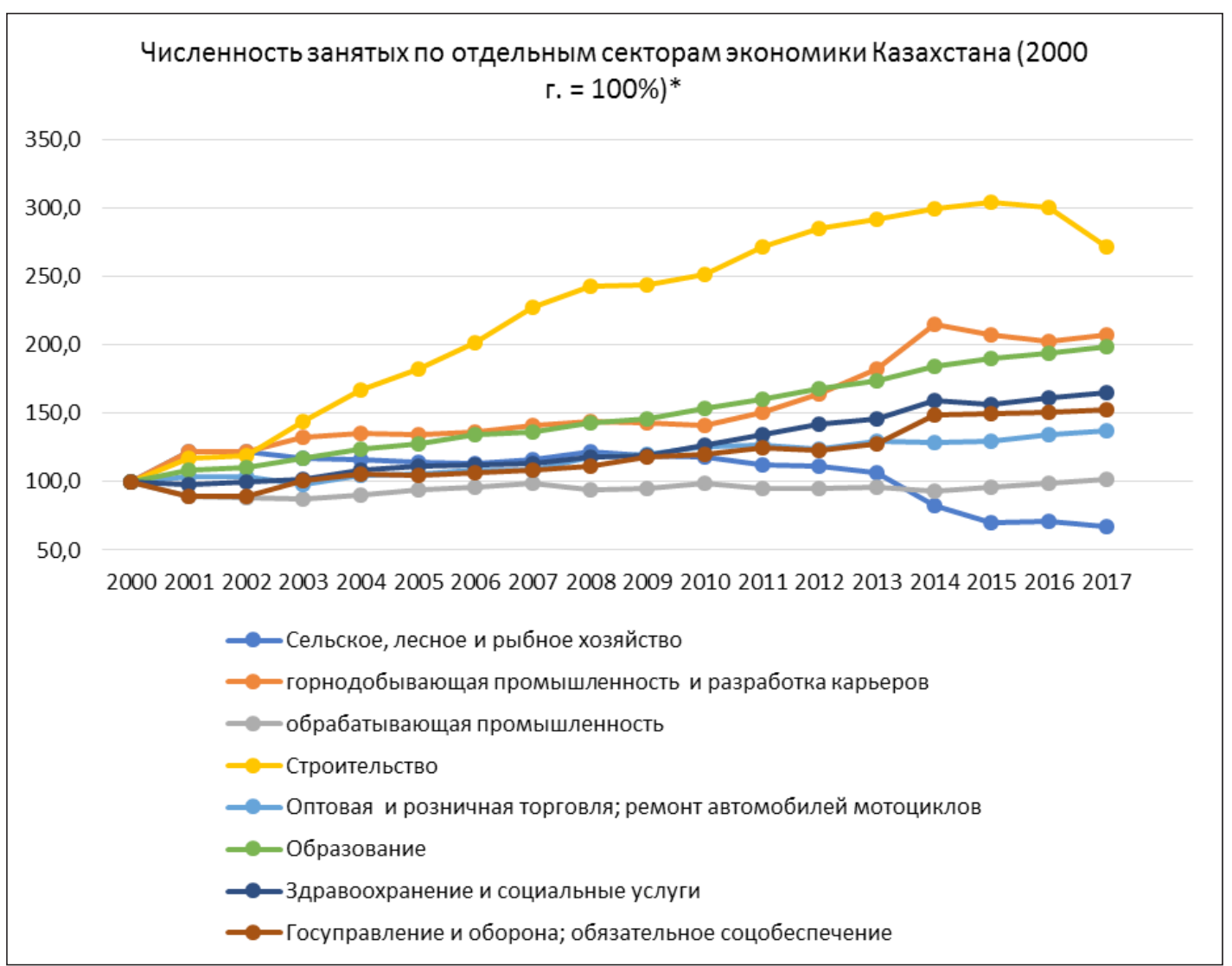

Рисунок 2 - Динамика численности занятых по отдельным секторам экономики Казахстана Примечание - составлено на основе (OECD Data. Unemployment)

Как видим, основной тренд занятости проявился в перетоке рабочей силы из сферы материального производства в сектор услуг. Особенностью является также слабое влияние кризисов 2008-2009 гг. и 2015-2016 гг. на численность занятого населения.

На рисунок 3 наглядно представлена динамика производительности труда и выпуска продукции в некоторых секторах экономики, из которой следует, что производительность труда по-разному влияет на рост выпуска и соответственно на величину занятости в них.

На рост совокупного платежеспособного спроса населения и соответственно на динамику темпов экономического роста оказало отрицательное влияние падение темпов роста реальной заработной платы за последние три года (рисунок 4). 


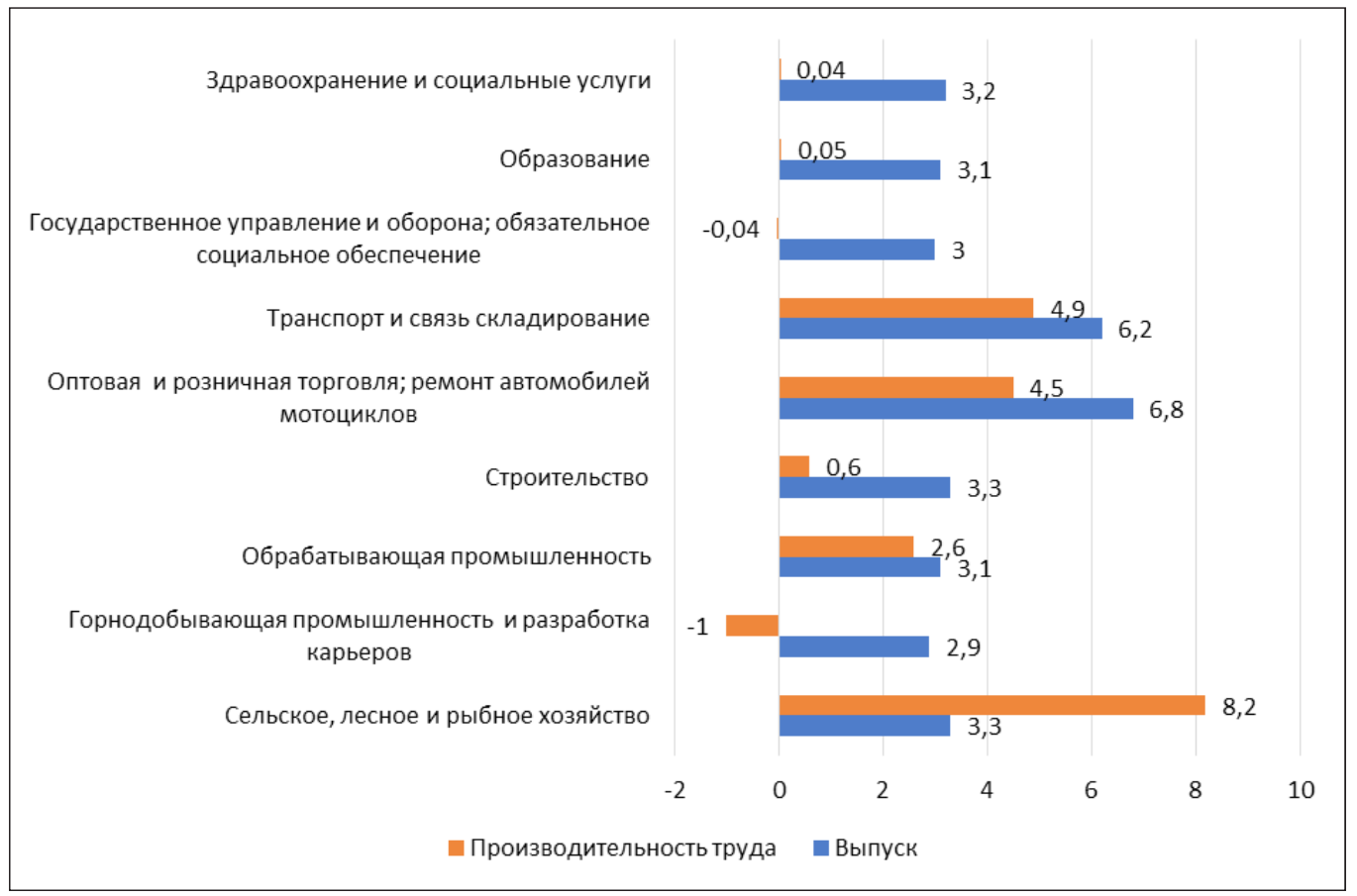

Рисунок 3 - Среднегодовые показатели производительности труда и выпуск продукции в период с 2007 по 2017 гг. Примечание - рассчитано и составлено на основе (OECD Data. Unemployment)

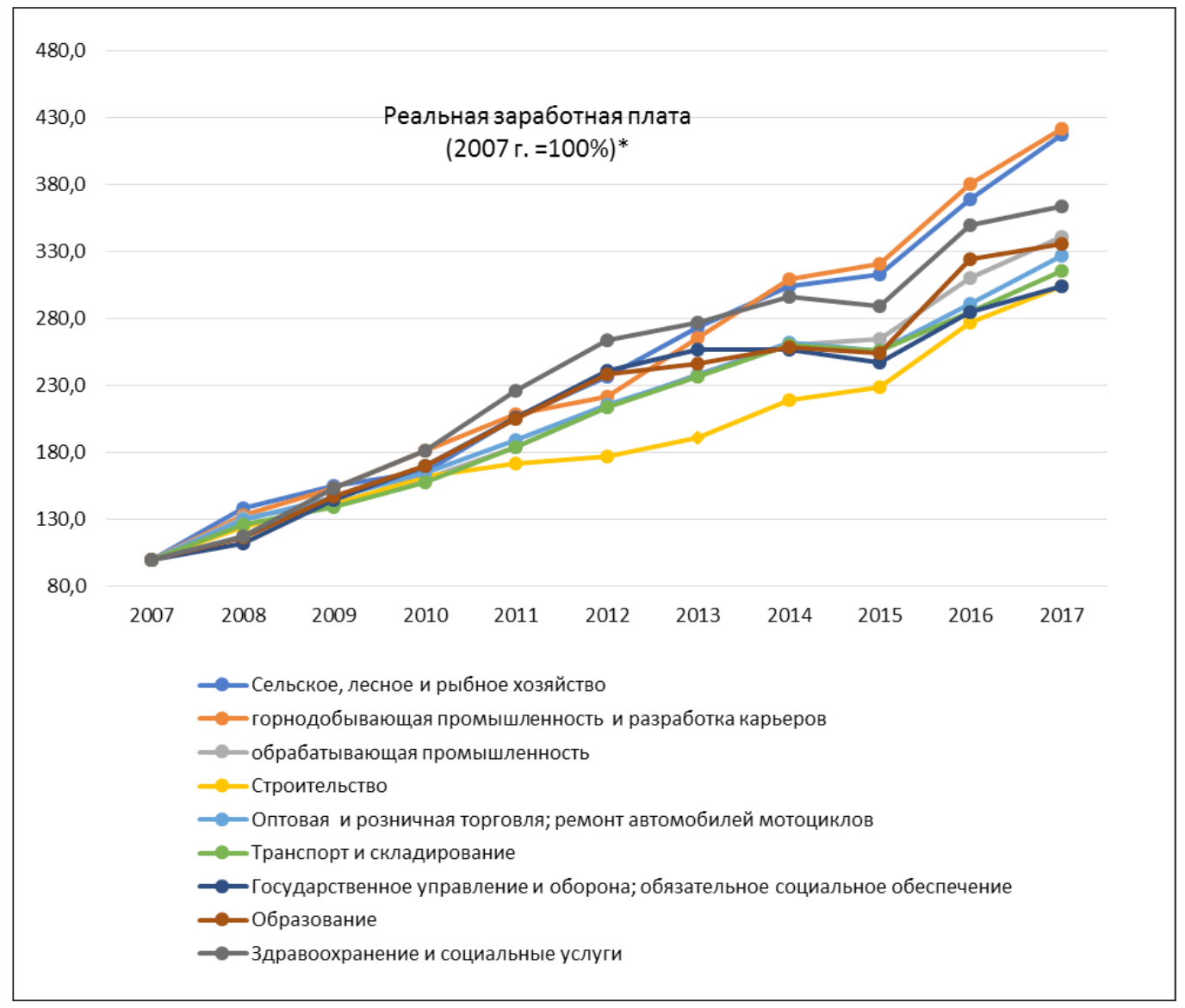

Рисунок 4 - Динамика реальной заработной платы в отдельных секторах экономики Казахстана Примечание - рассчитано и составлено на основе (OECD Data. Unemployment) 
Проведенный анализ показывает, насколько рынок труда гибко реагирует на воздействие различных факторов, в данном случае производительности труда и реальной заработной платы. Наши расчеты на основе статистических данных за период с 2001 по 2017 гг. показали, что корреляционная зависимость между занятостью населения и реальной заработной платой составила 0,449 ; между занятостью населения и производительностью труда - 0,042. Также добавим, что корреляционная зависимость между номинальной заработной платой и производительностью труда составила 0,481. Отсюда можно констатировать, что слабая зависимость между названными показателями и занятостью населения показывает, что в Казахстане заработная плата не стала по-настоящему инструментом стратегического управления, не сформировала в должной мере конкурентную среду на рынке труда, в результате консервируется дешевый труд, который тормозит модернизацию производства.

Кроме того, в казахстанской экономике также на динамику спроса на рабочую силу может оказать существенное влияние фактор недостаточного уровня инвестиционной активности: реальные инвестиции в основной капитал начиная с 2000 года росли, но в последние годы они заметно падали, а в 2017 г. их объем составил лишь 67,4\% от уровня 2013 года.

Отметим также, что ситуация на рынке труда в Казахстане складывается не только под воздействием комплекса мер косвенного государственного регулирования, но и мер прямого административного регулирования.

В данном исследовании автор исходил из того, что доминирующее влияние на изменение количественных характеристик спроса на рабочую силу на макроуровне могут оказывать следующие факторы: динамика ВВП, динамика инвестиций, динамика реальных доходов населения и заработной платы. На этой основе автором был применен конкретный методологический инструментарий прогнозирования спроса на рабочую силу. Он заключался в следующем: применив множественную регрессию, выявить корреляционную зависимость между численностью занятых и рядом факторов, которые оказывают на нее влияние; выбрать основные факторы, влияющие на результативный показатель, и затем построить уравнение множественной регрессии, позволяющей прогнозировать спрос на рабочую силу в масштабе национальной экономики страны.

\section{Обзор литературы}

Определенная теоретическая и методологическая база исследований на тему прогнозирования рабочей силы, разработанная западными и российскими учеными и специалистами, уже существует. Надо отметить, что их научные изыскания основаны на теоретическом и методологическом фундаменте, созданном в трудах классиков экономической науки - Дж. Кейнса, М. Фридмена, А. Маршала, Дж. Хикса и других авторов. На современном этапе значительный вклад в исследование рассматриваемой нами проблематики наряду с западными учеными - В. Францем (Franz, 2013), Р. Эренбергом, Р. Смитом (Ehrenberg, 1994) и другими, внесли российские экономисты, среди них необходимо выделить работы В.Е. Гимпельсона, Р.И. Капелюшникова, С.Г. Кузнецова, В.Н. Бобкова, Ю. Андрющенко и др.

В своих многочисленных работах В.Е. Гимпельсон и Р.И. Капелюшников комплексно и системно анализируют процессы, происходящие на российском рынке труда, в том числе потоки на рынке труда и изменения структуры занятости с широким применением современных эконометрических методов, тенденции занятости и безработицы, динамику заработной платы, различные структурные аспекты занятости (Гимпельсон, 2015; 2017).

Важные закономерности в связях между инновациями и занятостью исследовал Р. Капелюшников (Капелюшников, 2017). Согласно результатам проведенного им анализа, новые технологии гораздо сильнее влияют на структуру занятости, чем на ее уровень, при этом меняется не столько распределение работников по профессиям, сколько набор задач, решаемых в рамках каждой профессии.

Результаты их теоретических и методологических исследований могут служить важной основой построения конкретной методики прогнозирования занятости.

В работах С.Г. Кузнецова и его коллег предложена экономико-математическая модель прогнозирования структуры занятости по видам экономической деятельности и даются прогнозные оценки динамики спроса на рабочую силу (Кузнецов, 2005; 2008; 2010). Значительный интерес представляет статья В.Н. Бобкова и его коллег (Бобков, 2015), в которой ими проанализирован прогноз Минэкономразвития РФ по вопросам рынка труда и показана целесообразность отражения в прогнозах вновь принима- 
емых нормативных актов на состояние рынка труда и занятости населения, а также рассмотрены три варианта развития ситуации на рынке труда в России.

Российские авторы Ю. Андриенко, С. Гуриев, И. Денисова обстоятельно осветили международный опыт прогнозирования рынка труда. Авторы обращают внимание на следующие обстоятельства: в развитых странах прогнозированию рынка труда уделяется больше внимания, прогноз спроса на труд в странах ОЭСР строится на 5-10 лет с регулярным его обновлением. В прогнозировании рынка труда применяются количественный и качественный подходы. В частности, для количественного прогноза спроса на рабочую силу применяется метод требуемых трудовых ресурсов. Необходимым условием для него является макроэкономическое прогнозирование по секторам экономики (Андриенко, 2007). Также следует отметить материалы Круглого стола Гайдаровского форума, посвященные проблемам прогнозирования и моделирования рынка труда в России, где представлены методика прогноза спроса на рабочую силу и ее апробация для отдельных видов экономической деятельности (Гайдаровский форум, 2016).

\section{Результаты и обсуждение}

Отсутствие необходимых статистических данных не позволило прогнозировать величину и профессионально-квалификационную структуру спроса на рабочую силу в отдельных секторах экономики. Поэтому была предпринята попытка смоделировать спрос на рабочую силу на уровне национальной экономики, для анализа и прогнозирования которого имелись удовлетворительного качества статистические данные.

В экономической теории на макроуровне связь между ВВП и спросом на рабочую силу выражена достаточно определенно: рост ВВП ведет в той или иной степени к росту спроса на рабочую силу и наоборот. Кроме того, для анализа автором были взяты еще четыре фактора: инвестиции в основной капитал, реальная заработная плата, среднедушевые номинальные доходы населения и производительность труда. Регрессионный анализ на основе данных за 2001 2017 гг. дал следующие результаты: коэффициенты корреляции между численностью занятых и соответственно: показателем ВВП равнялся 0,64632 ; инвестициями в основной капитал 0,63698 ; реальной заработной платой - 0,44920; среднедушевыми номинальными доходами на- селения - 0,52258; производительностью труда - 0,041958. Таким образом, наиболее существенными факторами, влияющими на спрос на рабочую силу в казахстанской экономике, явились рост ВВП и инвестиции в основной капитал.

Для сравнения автором были проведены аналогичные расчеты на основе статистических данных для ряда развитых стран. Результаты подтверждают наличие тесной связи между численностью занятых и соответственно показателями ВВП и инвестициями в основной капитал. Так, в США коэффициенты корреляции между обозначенными показателями составили соответственно 0,82114 и 0,84294; в Великобритании $-0,788138$ и 0,76895; Германии $-0,42630$ и 0,56628; Франции - 0,40429 и 0,36950; Швеции - 0,44921 и 0,67335; Японии - 0,56818 и 0,79107.

Таким образом, в казахстанской практике на изменение численности занятых существенное воздействие оказывают в основном два фактора - динамика ВВП и инвестиций в основной капитал. На основе этого для прогноза изменения спроса на рабочую силу была выбрана степенная функция:

$$
I L=b_{0} * I Q^{b_{1} *} I i n v^{b_{2}}
$$

где $L$ - темп роста занятых; $I Q$ - темп роста ВВП;

Iinv - темп роста инвестиций в основной капитал.

В результате расчетов было получено следующее уравнение, отражающее модель прогноза спроса на рабочую силу в экономике Казахстана:

$$
\begin{gathered}
I L=3,29402 * I Q^{0,21287} * \operatorname{Iinv}^{0,07145}, \\
F_{\text {pacч. }}=5,76269 .
\end{gathered}
$$

Табличное значение критерия Фишера при обеспечении достоверности результата в 99\% составляет $F_{\text {табл. }}=2,94671$. Учитывая, что $F_{\text {раси }}$ $>F_{\text {табл. }}$, можно утверждать, что с допустимой ошибкой в 1\% данная модель адекватно отражает исходные данные и может быть использована для прогноза спроса на рабочую силу в экономике Казахстана.

Модернизация казахстанского рынка труда предполагает научно обоснованный анализ и как можно более точный прогноз занятости по экономике в целом для принятия эффективных макроэкономических решений при выработке социально-экономической политики государства. Этому будет способствовать включение в методологию макроэкономического прогнози- 
рования оценки влияния макроэкономических факторов развития на состояние рынка труда. По результатам данного исследования были выявлены основные факторы, которые влияют на изменение спроса на рабочую силу в экономике Казахстана: динамика ВВП и динамика инвестиций в основной капитал. Сопоставление их с аналогичными данными, полученными автором в результате анализа статистических данных по ряду развитых стран, подтверждает правильность выбора факторов для поставленной цели. Этот вывод послужил основой для разработки конкретного методологического инструментария прогнозирования спроса на рабочую силу для Казахстана.

Эконометрическая модель прогнозирования величины спроса на рабочую силу разработана для экономики в целом с учетом изменений в динамике ВВП и инвестиций в основной капитал. Опыт ее разработки может быть полезен при прогнозировании спроса на рабочую силу на уровне отдельных отраслей в разрезе профессиональноквалификационных групп. Для прогноза спроса на рабочую силу с использованием трендов отраслевой структуры занятости необходимо совершенствование статистики и наличие данных на уровне предприятий, отражающих изменение занятости под воздействием различных факторов, разработка стандартных систем классификаций профессий и квалификаций.

Полученные результаты могут стать толчком для проведения широких исследований по комплексному анализу и прогнозированию спроса на рабочую силу на рынке труда в Казахстане, выводы и рекомендации которых послужат основой разработки нормативно-правовых актов, определяющих новые черты модернизированного рынка труда.

\section{Заключение}

На величину спроса экономики на рабочую силу в Казахстане влияют темпы роста ВВП, динамика инвестиций в основной капитал, изменение заработной платы и другие факторы. Наш анализ показал, что первые два фактора являются доминирующими и изменение численности занятых преимущественно подвержено их влиянию. В свою очередь, темпы роста ВВП сильно зависят от структуры экономики, в этом отношении сырьевая направленность производства и недостаточное развитие высокотехнологичных производств сдерживают экономический рост. Значительное влияние на динамику и структуру спроса на рабочую силу оказывает фактор недостаточного уровня инвестиционной активности. Определенную роль играет падение темпов роста реальной заработной платы в последние годы, что сдерживает рост совокупного платежеспособного спроса и это отрицательно сказывается на динамике темпов экономического роста.

Для принятия эффективных макроэкономических решений возрастает значение надежных инструментов прогнозирования спроса на рабочую силу на рынке труда. Для этого государство должно заняться формированием современной инфраструктуры рынка труда. Мировой опыт подсказывает, что оценке текущего состояния рынка труда и прогнозированию потребности в кадрах различного профиля и квалификации нужно придать приоритетное значение. Прогноз спроса на труд целесообразно рассчитывать по меньшей мере на 5 лет с периодическим его обновлением. К результатам прогноза должен быть обеспечен широкий доступ путем ее размещения в Интернете, на сайте Министерства труда и социальной защиты населения РК, рассылки в школы. Они станут индикатором перспектив на рынке труда для разного уровня образования, в значительной степени обеспечат лучшее соответствие между подготовкой кадров и спросом на рабочую силу определенной профессионально-квалификационной структуры.

Давно назрела необходимость создания Института (центра) трудовых исследований, финансируемого из государственного бюджета через соответствующие министерства. Полагаем, расширение тематики фундаментальных исследований и программно-целевых проектов по проблемам прогнозирования рынка труда позволит преодолеть серьезное отставание в этом вопросе от развитых стран и России.

Работа выполнена в рамках проекта: АР05135300 «Модернизация рынка труда как составная часть механизма реализации третьей модернизации Казахстана: теоретические и прикладные проблемь и перспективы их решения», финансируемого МОН РК 


\section{Литература}

Андриенко Ю., Гуриев С., Денисова И. Прогнозирование рынка труда: международный опыт и возможные пути развития в России. - 22 января 2007, http://hnu.docdat.com/

Бобков В.Н., Аникеев С.Д., Локтюхина Н.В., Рожков В.Д., Пироженко Е.А. О состоянии и прогнозе развития рынка труда и занятости населения Российской Федерации (2006-2017 гг.) // Уровень жизни населения регионов России. - 2015. - №1. - С. 8-22.

Гимпельсон В.Е., Капелюшников Р.И. Российская модель рынка труда: испытание кризисом // Журнал Новой экономической ассоциации. - 2015. - № 2, С.249-254.

Капелюшников Р. Технологический прогресс - пожиратель рабочих мест? // Вопросы экономики. - 2017. - № 11. C. 111-140.

Комитет по статистике МНЭ РК 2017. Труд, http://stat.gov.kz/

Комитет по статистике МНЭ РК 2018. Основные социально-экономические показатели РК 1991-2018 гг., http://stat.gov.kz/

Кузнецов С.Г. Методология макроэкономического анализа и прогнозирования спроса на рабочую силу и ее предложения. - 2005, http://economy-lib.com/

Кузнецов С.Г., Кузьмин В.В., Кулагина Н.М., Попов А.Д. Проблемы прогнозирования параметров занятости и рынка труда / Научные труды: Институт народнохозяйственного прогнозирования РАН. - 2010. - Т. 8. - С. 703-726.

Кузнецов С.Г., Мухина И.И. Методология прогнозирования эффективной структуры занятости в условиях инновационного сценария макроэкономического развития / Научные труды: Институт народнохозяйственного прогнозирования PAH. - 2008. - C. 806-833.

Мобильность и стабильность на российском рынке труда / Под общ. ред.: Р.И. Капелюшников, В.Е. Гимпельсон. - М.: Издательский дом НИУ ВШЭ. - 2017. - 800 с.

Прогноз спроса на рабочую силу и производительности труда по видам деятельности на кратко- и среднесрочную перспективу // Круглый стол «Проблемы прогнозирования и моделирования рынка труда в России» Гайдаровский Форум. - 2016, https://iep.ru/

Ehrenberg R.G., Smith R.S. Modern labor economics: theory and public policy. $-5^{\text {th }}$ ed. Harper Collins College Publishers. 1994. - Chapters 3-5, pp. 58-163.

Franz W. Arbeitsmarktoekonomik. 6.Auflage. - Springer Gabler. - 2013. - Kapitel Die Arbeitsnachfrage, Seiten 107-184.

OECD Data. Unemployment, https://data.oecd.org/

\section{References}

Andrienko Yu., Guriev S., Denisova I. (2007) Prognozirovanie ryinka truda: mezhdunarodnyiy opyit i vozmozhnyie puti razvitiya v Rossii [Forecasting the labor market: international experience and possible development paths in Russia], http://hnu.docdat. $\mathrm{com} /$

Bobkov V.N., Anikeev S.D., Loktyuhina N.V., Rozhkov V.D., Pirozhenko E.A. (2015) O sostoyanii i prognoze razvitiya ryinka truda i zanyatosti naseleniya Rossiyskoy Federatsii (2006-2017 gg.) [On the state and forecast of the development of the labor market and employment of the population of the Russian Federation (2006-2017)]. Uroven zhizni naseleniya regionov Rossii, vol. 1 , pp. 8-22.

Ehrenberg R.G., Smith R.S. (1994) Modern labor economics: theory and public policy. $5^{\text {th }}$ ed. Harper Collins College Publishers, chapters 3-5, pp.58-163.

Franz W. (2013) Arbeitsmarktoekonomik. 6.Auflage. Springer Gabler, Kapitel Die Arbeitsnachfrage, pp. 107-184

Gimpelson V.E., Kapelyushnikov R.I. (2015) Rossiyskaya model ryinka truda: ispyitanie krizisom [Russian labor market model: a test of crisis]. Zhurnal Novoy ekonomicheskoy assotsiatsii. vol. 2, pp. 249-254.

Kapelyushnikov R. (2017) Tehnologicheskiy progress - pozhiratel rabochih mest? [Technological progress - job eater?]. Voprosyi ekonomiki, vol. 11, pp. 111-140.

Komitet po statistike MNE RK 2017. Trud [Committee on Statistics of the MNE RK 2017. Labor], http://stat.gov.kz/

Komitet po statistike MNE RK 2018. Osnovnyie sotsialno-ekonomicheskie pokazateli RK 1991-2018 gg. [The Committee on Statistics of the MNE RK 2018. Main socio-economic indicators of the Republic of Kazakhstan 1991-2018], http://stat.gov.kz/

Kuznetsov S.G. (2005) Metodologiya makroekonomicheskogo analiza i prognozirovaniya sprosa na rabochuyu silu i ee predlozheniya [Methodology of macroeconomic analysis and forecasting of labor demand and its supply], http://economy-lib.com/

Kuznetsov S.G., Kuzmin V.V., Kulagina N.M., Popov A.D. (2010) Problemyi prognozirovaniya parametrov zanyatosti i ryinka truda [Problems of forecasting the parameters of employment and the labor market]. Nauchnyie trudyi: Institut narodnohozyaystvennogo prognozirovaniya RAN, vol. 8, pp. 703-726.

Kuznetsov S.G., Muhina I.I. (2008) Metodologiya prognozirovaniya effektivnoy strukturyi zanyatosti v usloviyah innovatsionnogo stsenariya makroekonomicheskogo razvitiya [Methodology of forecasting the effective structure of employment in the context of the innovation scenario of macroeconomic development]. Nauchnyie trudyi: Institut narodnohozyaystvennogo prognozirovaniya RAN, pp. 806-833.

Mobilnost i stabilnost na rossiyskom ryinke truda [Mobility and stability in the Russian labor market] / Pod obsch. red.: R.I. Kapelyushnikov, V.E. Gimpelson (2017). M.: Izdatelskiy dom NIU VShE, 800 p.

OECD Data. Unemployment, https://data.oecd.org/

Prognoz sprosa na rabochuyu silu i proizvoditelnosti truda po vidam deyatelnosti na kratko- i srednesrochnuyu perspektivu [Forecast of labor demand and labor productivity by type of activity for the short and medium term] (2016) Kruglyiy stol «Problemyi prognozirovaniya i modelirovaniya ryinka truda v Rossii» Gaydarovskiy Forum, https://iep.ru/ 